\title{
SZAKÁcs BoglárKA*
}

\section{BARTÓK BÉLA: CONCERTO ZENEKARRA. TÖRÖK INSPIRÁCIÓ EGY REMEKMÚBEN}

\author{
Kulcsszavak: török népzenegyüjtemény, Concerto, inspiráció, Bartók Béla
}

A zenekari Concerto Bartók Béla egyik legismertebb, legnépszerúbb kompozíciója. Számtalan elemzés született már a dallamok eredetére, akárcsak különböző inspirációs forrásokra vonatkozóan, amelyeket a zeneszerző használ. Részletes elemzést ezekről David Cooper, Elliot Antokoletz, John McCabe és Somfai László készített.

Ismert tény, hogy a folklorista Bartók munkája nyomon követhető a zeneszerző zenéjében is. A magyar, román, szlovák népzene hatása tagadhatatlan. A keleti gyưijtésnek kisebb, de nem kevésbé jelentős a befolyása a bartóki életműre. Kárpáti János részletezi a távol-keleti hatásokat Bartók zenéjében, arab zene befolyása érezhető például az Op. 14-es Zongoraszvit, a második és negyedik Vonósnégyes, a Hegedúduók, a Csodálatos mandarin vagy - legelokvensebb példaként - a Táncszvit esetében is.

A török népzenének látszólag azonban nem volt erős befolyása Bartók életművében. László Ferenc ezt határozottan ki is jelenti: „A török zene nem hagyott kimutatható nyomot Bartók zeneszerzői művében, alighanem azért, mert számára a törököknél a döntő élményt nem a másmilyenség, hanem éppen hogy a rokonság felfedezése jelentette". ${ }^{1}$ Bartók stílusában valóban nem találunk specifikus elemet, amely a török népzene révén ivódott volna bele a műveibe. Azonban a Concertoban felfedezhető egy konkrét részlet egy török dallamból, melyet a népzenetudós Bartók jegyzett le Isztambulban.

Ugyanabban az időszakban, amíg a Concertón dolgozott, tehát 1943-ban, Bartók a török gyújteménye kiadását készítette elő. Természetesnek tưnik, hogy a török anyagnak történetesen hatása volt erre a kompozícióra. A zeneszerző a nyitó és a harmadik tételben használta fel azt a dallamot, amelyet Isztambulban jegyzett le.

Említésre méltó tény, hogy a Concerto vázlatai ugyanabban a füzetben vannak, mint amelyben a Törökországban gyújtött és lejegyzett dallamok². Mielött útnak indult volna Ankarába és Anatóliába, a folkloristának lehetósége volt arra, hogy 65 fonográffelvételt is végighallgasson helyi előadóktól, többnyire parasztoktól, akiket környező falvakból hívtak be. Bartók gyűjiőfüzetének első két oldalán két, Isztambulban lejegyzett népdal tünik fel.

1943-ban a zenekari Concerto egy hosszú, terméketlen periódust szakított meg a magyar zeneszerző életében. A remekmú a 20. század emblematikus alkotásává vált. A kompozíció

\footnotetext{
* Szakács Boglárka (1994), magiszteri hallgató, BBTE Református Tanárképző és Zeneművészeti Kar. E-mail: szakacsb@yahoo.com.

1 LÁszló Ferenc: Bartók markában. Polis, Kvár, 2006. 140. Vö. továbbá: Bartók-dolgozatok. Szerk. LÁszló Ferenc. Kriterion, Bukarest, 1974; Bartók-dolgozatok 198. Szerk. LÁszLó Ferenc. Kriterion, Bukarest, 1982.

2 NYBA Ms, 8OFSS1 jelzet, Bartók Archívum, Zenetudományi Intézet, Budapest.
} 
szoros kapcsolatban áll Bartók fiatalkori múveivel, nemcsak a zenei nyelvezetben, hanem a szerkezetében is (például az I. zenekari szvit, egy öttételes mú és a negyedik és ötödik vonósnégyes). Egy másik közös tulajdonság az úgynevezett „szimfonikus karakter”, melyet maga a szerző magyaráz a zeneműve elemzésében. „Az általános hangulata a műnek”, írja Bartók, „a második tétel kivételével egy nagy átmenetet képvisel az első tétel szigorúságától és a harmadik tétel halál-énekétől és az életigazoló negyedik tételtől.”3 1943 augusztusában kezdte el írni az öttételes Concertót, kevésbé nyíltan szimmetrikus formában, mint korábbi öttételes kompozícióit. Az új alkotás 45 nap alatt készült el. ${ }^{4}$ Általános stílusában a népzene és klasszikus zene variálása kevésbé érzékelhető, mint az 1930-as évek termésében. A múvet Bartók Concertónak nevezte el arra való tekintettel, hogy „az egyes hangszerek olyan viszonyba vannak, mint a concertáló rész a szólóval”. ${ }^{5} \mathrm{~A}$ belső szerkezete a műnek azonban szvitszerű. Az Introduzione (Andante non troppo) egy kvártra épülő témával indít. Az Allegro vivacet (Allegretto scherzando) sajátos dallam és táncritmus jellemzi, az Elegia (Andante non troppo) szenvedélyes kifejezésű, úgymond impresszionista és romantikus hangvételű, az Intermezzo interrotto (Allegretto) valójában egy zseniális scherzo, fantasztikus és költői, míg a Finale (Pesante. Presto) dinamikával teli, egy erdélyi tánc ritmusát hozza. ${ }^{6}$ A mű hangszerelése gazdag, a vonósokat fa- és rézfúvósok, ütőhangszerek és két hárfa egészítik ki.

A Concerto vázlatai a zeneszerző három, vázlatokat és átiratokat tartalmazó füzete közül a másodikban találhatók. Amint már fentebb említettük, ez a második füzet tartalmazza a Törökországban 1936-ban lejegyzett dallamokat.

A Concerto ősbemutatója 1944-ben volt, egy évvel a zeneszerző halála előtt. Az első előadás a Boston Symphony zenekar előadótermében volt, a megrendelő, Serge Koussevitzky vezényletével, aki állandó karmestere is volt a zenekarnak 1924-1949 között.

A továbbiakban a mű elemzésére térünk ki, a tételek főbb témáit és esetleges forrásaikat ismertetve. Az elsô részben, Introduzione, a zenei forma szempontjából egy kétrészes forma figyelhető meg, két különböző tempójelzéssel: Andante és Allegro. A lassú része ennek a tételnek - Andante - dramatikus töltetű, az első téma a kvárt hangközökre épül, amely fontos helyet foglal el a dallam formálásában. Ezt a témát cselló és nagybőgő szólaltatja meg, amelyek fölött tremolóval játszanak a felső szólamú vonósok és fuvolák.

3 Joseph Machlis: Introduction to Contemporary Music. Second edition. Ed. W. W. Norton\&Company, New York, 1979. 435.

4 A New York-i kórházban való tartózkodása során Bartók barátja, Szigeti József hegedűs felkereste Serge Koussevitzky karmestert, felbiztatva őt arra, hogy Bartók Bélát kellene megbíznia egy új zenekari mú megírásával. A karmester meglátogatta a kórházban a zeneszerzőt, és megrendelte a múvet. Kérése az volt, hogy zenekari darab legyen, és a karmester felesége, Natalie Koussevitzky emlékének dedikálja a szerző. Bartók egy hónappal később hazatért a kórházból, kiköltözött egy szanatóriumba a Saranac-tónál, július 1-től október 12-ig tartózkodott ott. Ebben az időszakban, augusztus 15. és október 8. között írta meg a zenekari Concertót.

5 Machlis: i. m. 435.

6 Vasile Ilıut: De la Wagner la contemporani. IV. Editura Muzicală, București, 1998. 260-261. 


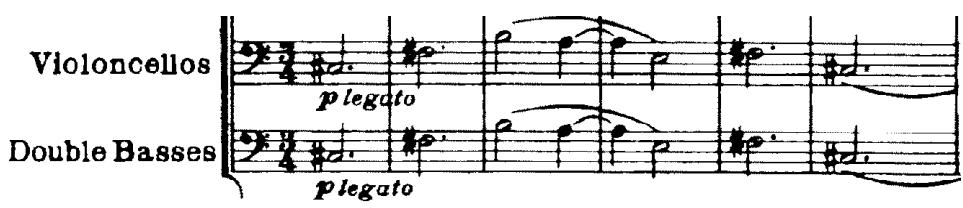

1. kottapélda. Bartók Béla: Concerto zenekarra (Introduzione, 1-6. ü.)

Az Andante részben az első témát követôen a 30. ütemben, a második témát a fuvola játszsza, itt jelenik meg az a török téma, amelyet Bartók jegyzett le Isztambulban, és a Concerto vázlatai mellett található.

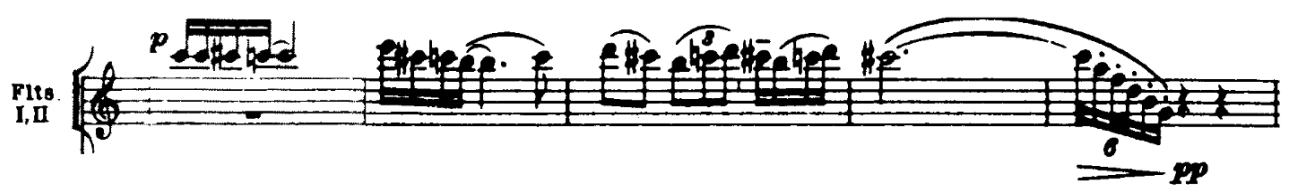

2. kottapélda. Bartók Béla: Concerto zenekarra (Introduzione, 30-34. ü.)

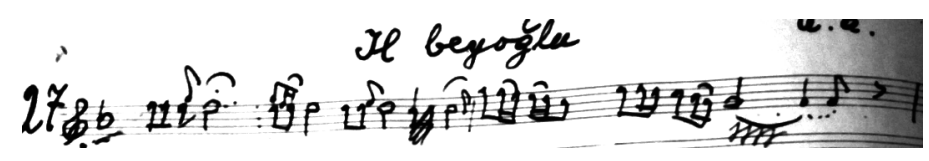

3. kottapélda. Il beyoğlu (Bartók által lejegyzett dallam, facsimile, NYBA Ms, 8OFSS1 jelzet, Bartók Archioum, Zenetudományi Intézet, Budapest)

Ezt a harmonizált dallamot, melyet a három trombita intonál a 39-42. ütemekben, David Cooper muzikológus parlando-rubato-típusú szintetikus dallamként nevezi meg:

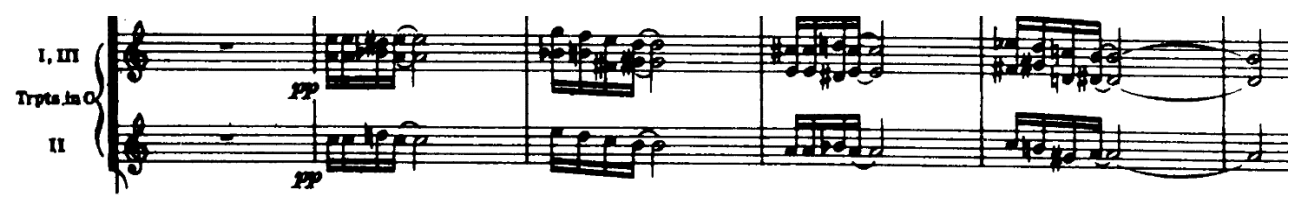

4. kottapélda. Bartók Béla: Concerto zenekarra (Introduzione, 39-42. ü.)

Az első tétel főtémája a Parry-gyújtemény egyik dallamából inspirálódott. A melódia a szerb-horvát népzene egy jellegzetes skálája körül rajzolódik ki, amely a következő szekvenciát tartalmazza: $F-G-A s z-B-C e s z$. Ebben a gyüjteményben Bartók nagyon különös skálaformaként nevezi meg ezt a hangsort.

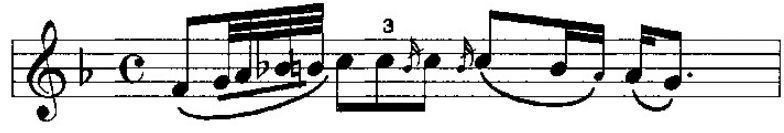

5. kottapélda. A dallam a szerb-horvát Hősi énekek gyújteményben.

Milman Parry-Albert B. Lord-Béla Bartók, no. 27c 


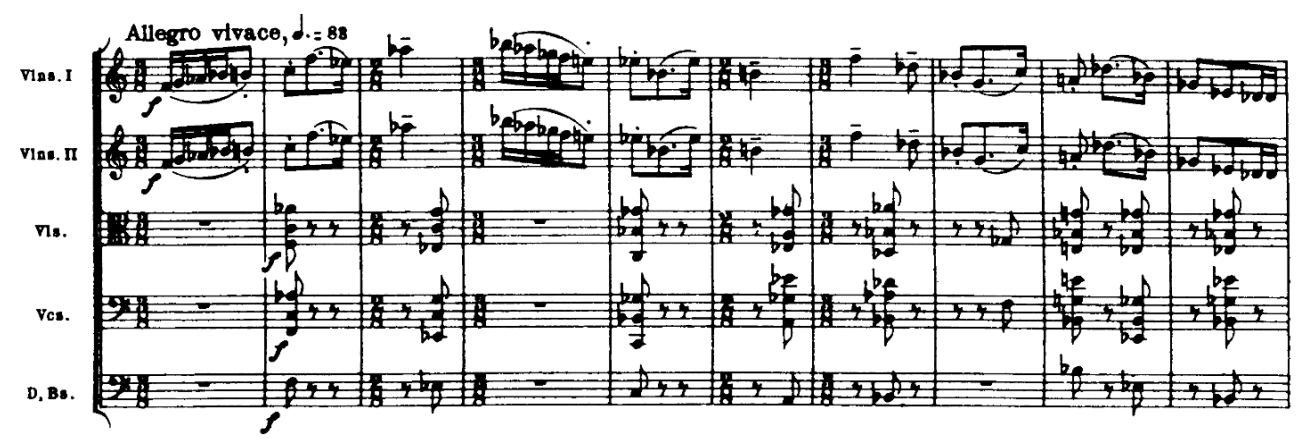

6. kottapélda. Bartók Béla: Concerto zenekarra (Introduzione, 76-85. ü.)

Az expozíciónak a középső részében egy lírai téma jelenik meg, amely a nosztalgikus dallamra utal az Intermezzóból, és nem ismétlődik meg az első rész reprízében. A témacsoport egy „riasztással” fejeződik be, melyet új, tranquillo jelzésű dallam követ, melyet az oboa nagyon szúk hangkészlettel játszik (előbb csak egy lengés két hang között). Ez a motívum egy arab dallamot idéz fel, melyet Bartók Észak-Afrikában gyưjtött.

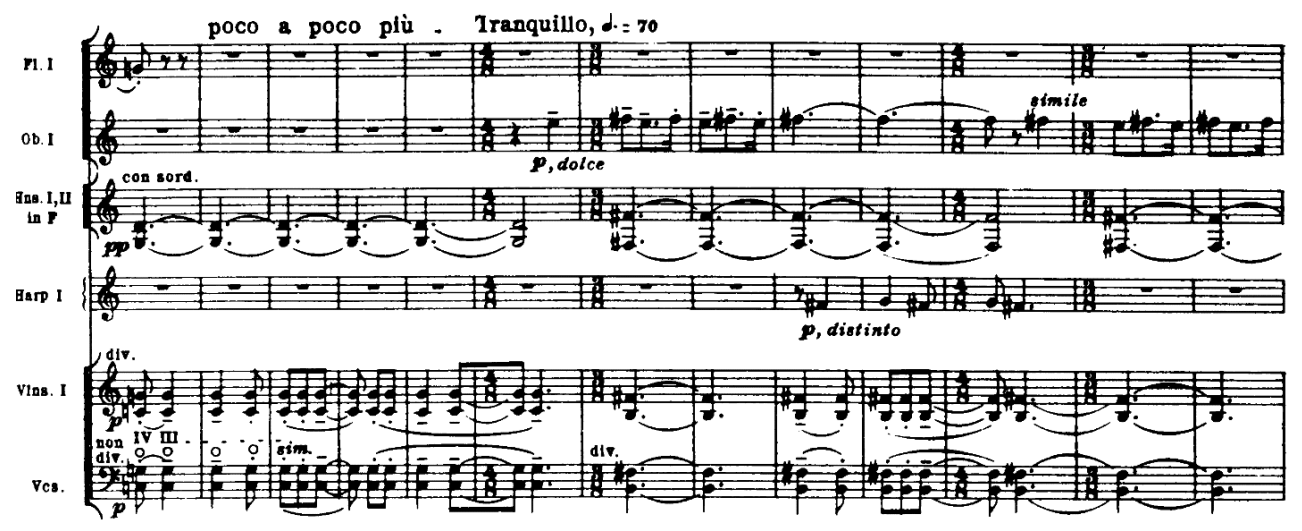

7. kottapélda. Bartók Béla: Concerto zenekarra (Introduzione, 142-162. ü.)

A kidolgozási részben egy, a fafúvósok által játszott epizód idézi vissza a második témát, a török dallamot.

A zenekari mű második tétele (Giuoco delle coppie) a szerző megfogalmazása szerint is az egyetlen humorral teli rész. Ez megszakítja a folyamatot az első tétel komoly hangulatától egészen az „életről való lemondásig” az utolsó tételben. „A II. tételt hallgatva igazolódni látszik a feltételezés, hogy a Concerto komponálásához Bartók egy korábban elkezdett és félbemaradt szimfonikus balettzene vázlatanyagát is felhasználta. A második tétel színpadi tánc, egy bensőséges pas de deux lépéssorozatának benyomását kelti”7 - fogalmaz a Bartók-kutató

7 TAllián Tibor: Bartók Béla. Rózsavölgyi és Társa, Bp., 2016. 379. 
Tallián Tibor. A Concerto második részében egy „páros játék” figyelhető meg, amelyben a zeneszerző imitálta a Parry-gyüjteményben talált két párhuzamos dalmáciai stílust. ${ }^{8}$

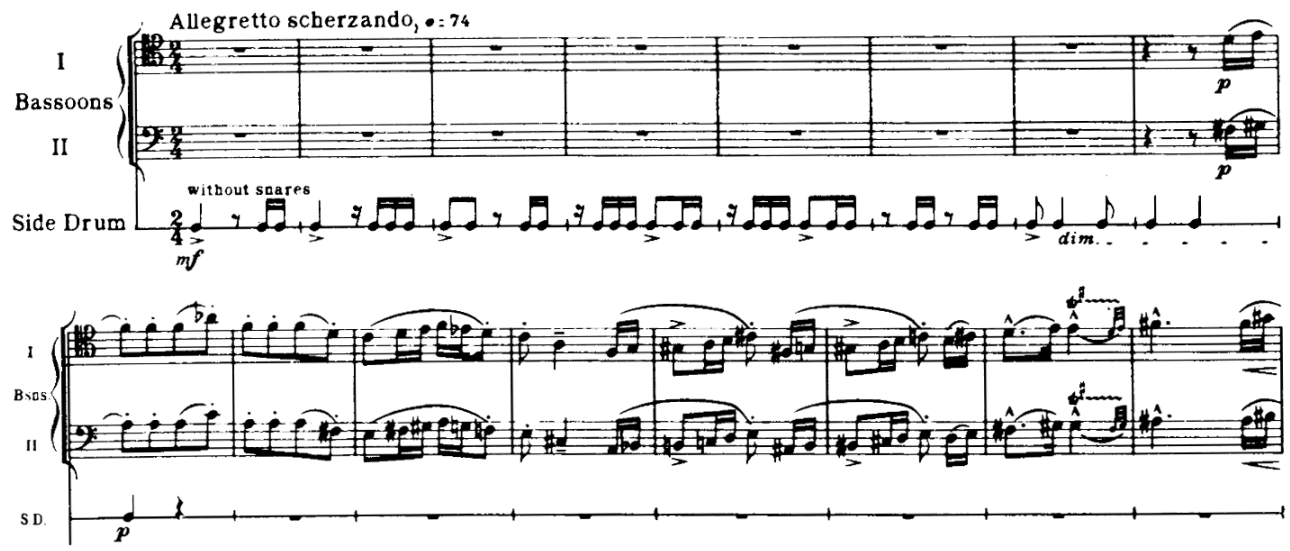

8. kottapélda. Bartók Béla: Concerto zenekarra (Giuoco delle coppie, 8-16. ü.)

A harmadik, Elegia az előző tételekkel ellentétes tempóban jelenik meg, hangsúlyozva a tragikus hangulatot. Bartók ciklikus gondolkodása érhető itt tetten, ugyanis egy kvártból épülő motívummal nyit, ugyanabban a formában, mint ahogy az megjelent az Introduzione harmadik ütemének utolsó ütésében, azzal a különbséggel, hogy itt a nagybőgók intonálják.

A népzenei inspirációs forrásokon kívül a Concertoban Bartók megelevenít pillanatokat más, saját kompozícióiból is. Egy sötét motívummal, hárfa-glissandókkal és a fuvola-klarinét párbeszéddel idézi meg az Elégia a könnyek tava motívumot a Kékszakállú herceg vára címú operából.

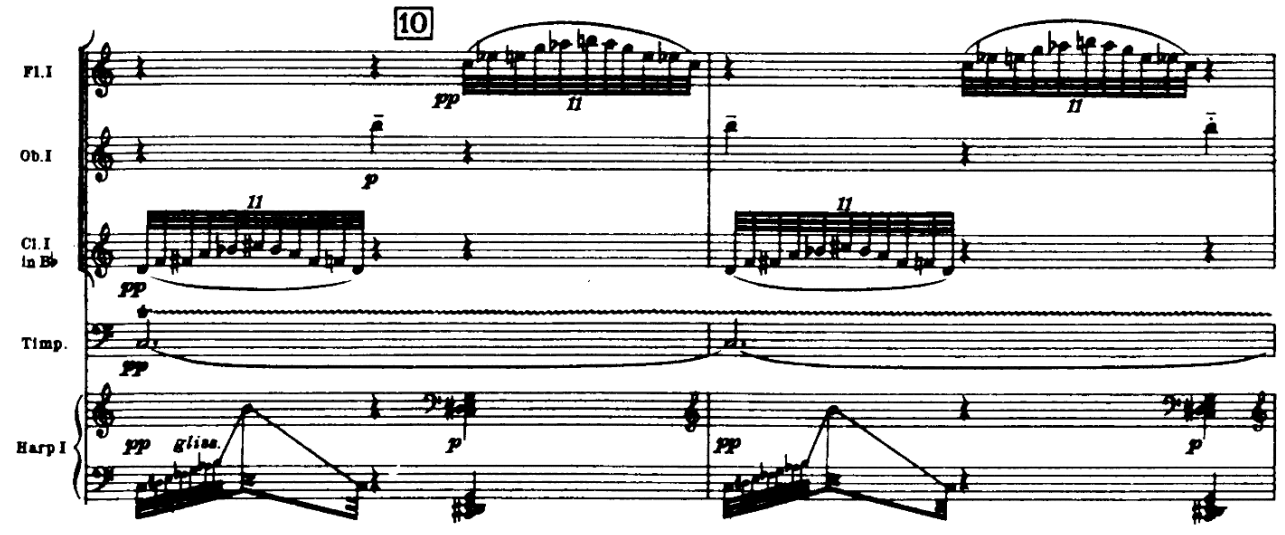

9. kottapélda. Bartók Béla: Concerto zenekarra (Elegia, 10-11. ̈̈.)

8 The New Grove Dictionary of Music and Musicians. II., IV. Oxford University Press, New York, 2005. 805. 


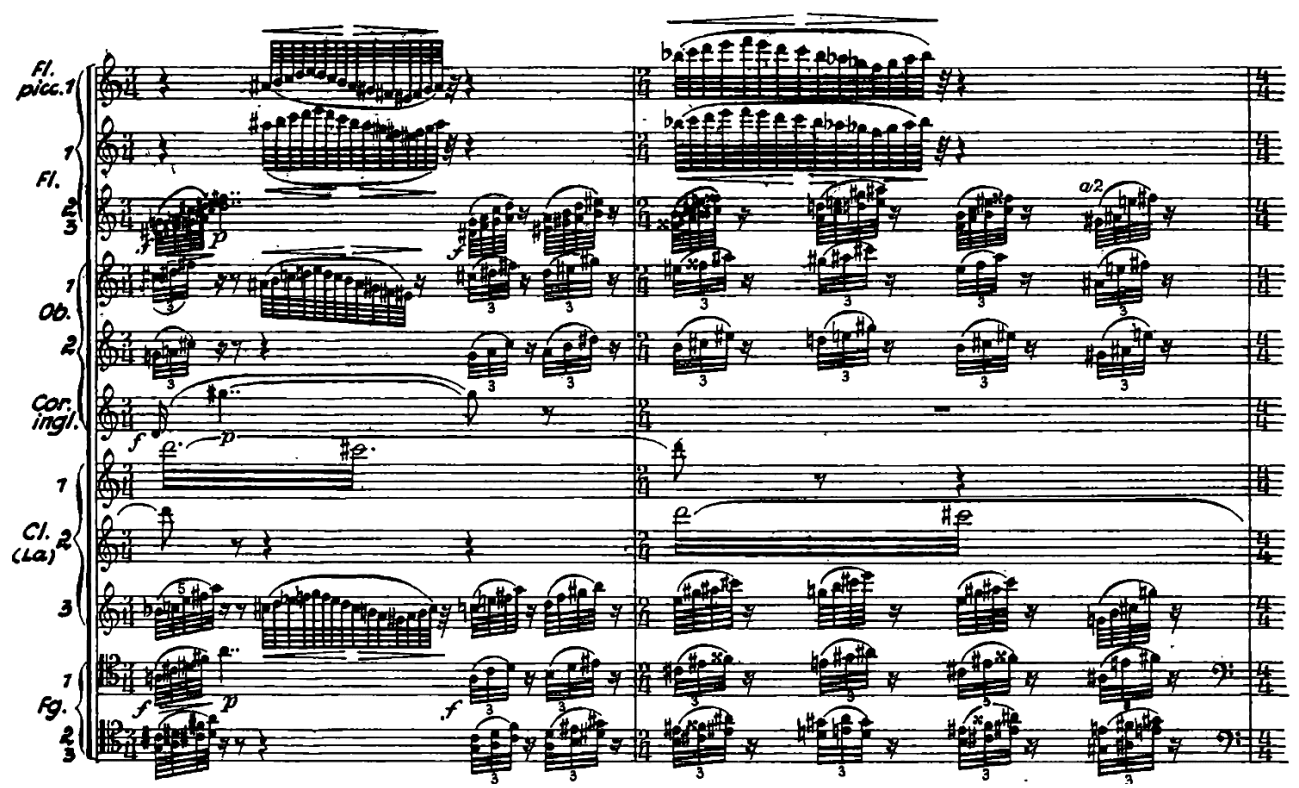

10. kottapélda. Bartók Béla: A kékszakállú herceg vára (részlet)

Az analízisben, melyet Bartók készített ehhez a kompozícióhoz, ő maga „gyászéneknek” nevezi a részt, és a téma valóban gyászzenei hangulatot sugall.

Ebben a tételben a zeneszerző visszatér a török témához, amelyet Isztambulban jegyzett le, és már használt az Introduzione Andante részében. Az új közegben azonban a dallam gazdag hangzással és jóval kihangsúlyozottabb drámai töltettel jelenik meg.

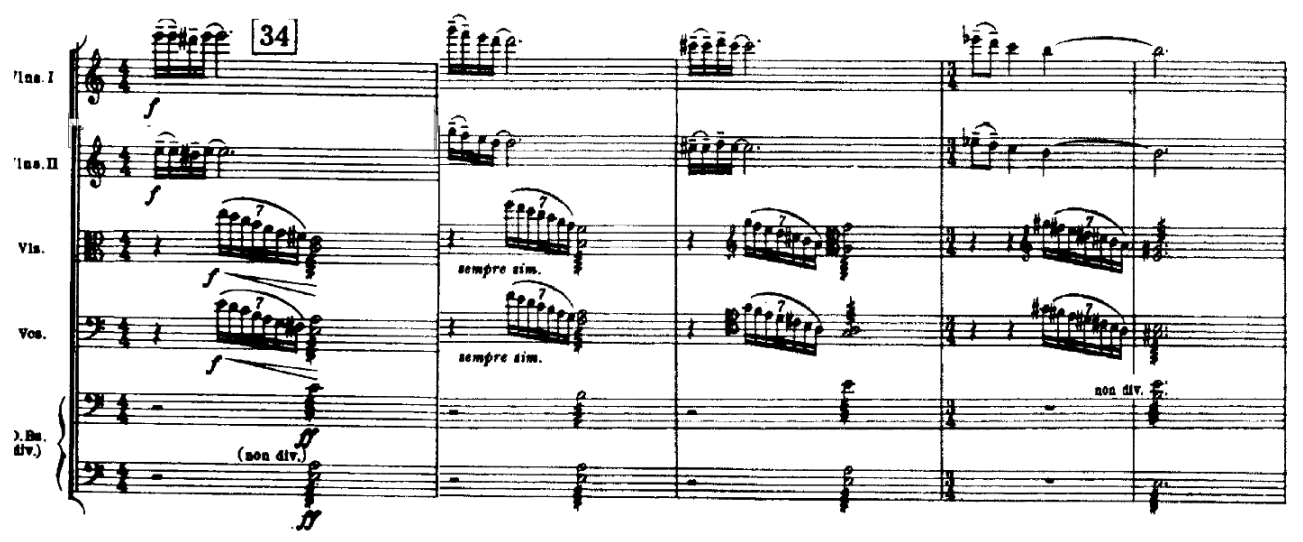

11. kottapélda. Bartók Béla: Concerto zenekarra (Elégia, 34-38. ü.)

Az inspirációk forrása folytatódik a darabban, az alább látható téma, amelyet a brácsa játszik, egy paraszt sírását idézi meg kromatikus variációban. 


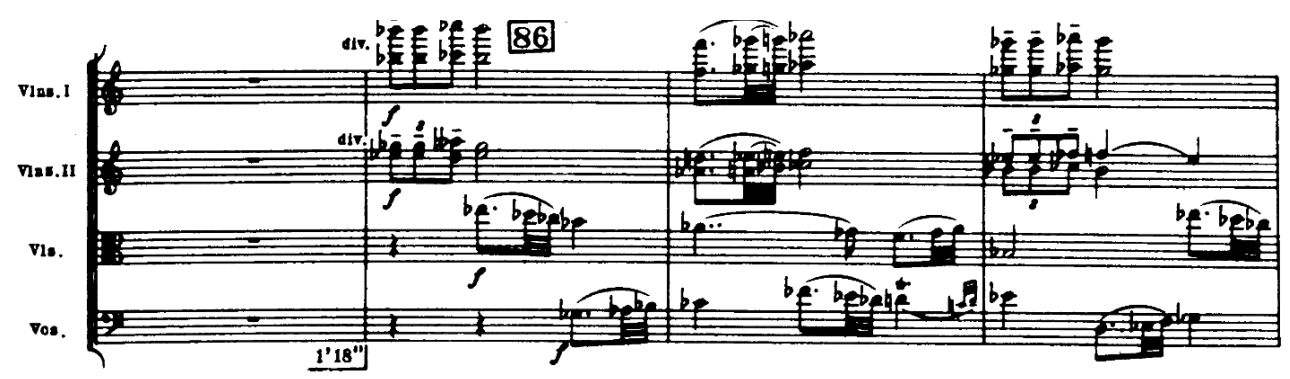

12. kottapélda. Bartók Béla: Concerto zenekarra (Elégia, 85-88. ü.)

A negyedik tételről - Intermezzo - Bartók maga vallja, hogy az egyetlen „programatikus tétel” ebben a múben. A szerkezete $\mathrm{A}-\mathrm{A}-\mathrm{B}-\mathrm{A}$ forma, az inspirációk tere itt már a török, horvát és magyar népzenei elemekről kiterjed egy némiképp váratlan területre. $\mathrm{A} B$ rész alapját képező, kifejező dallamíve a hegedúknek valójában egy részlet variánsát képezi Vincze Zsigmond A hamburgi menyasszony című operettjéből. A dalt - „Szép vagy, gyönyörű vagy, Magyarország” - Sándor György zongorista azonosította, aki Amerikában találkozott Bartókkal. Sándor György számára nem volt egyszerú felismerni az inspiráció forrását, Bartók ugyanis nem közvetlenül idézi a dallamot.

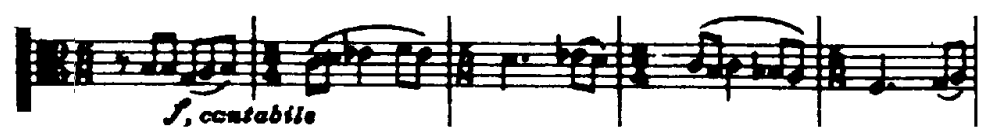

13. kottapélda. Bartók Béla: Concerto zenekarra (Intermezzo interrotto, 42-46. ü.)

A források palettája tovább szélesedik ebben a tételben, a zeneszerző ugyanis parodizált egy részt Dimitrij Sosztakovics zeneszerző Hetedik, „Leningrád” Szimfóniajából.

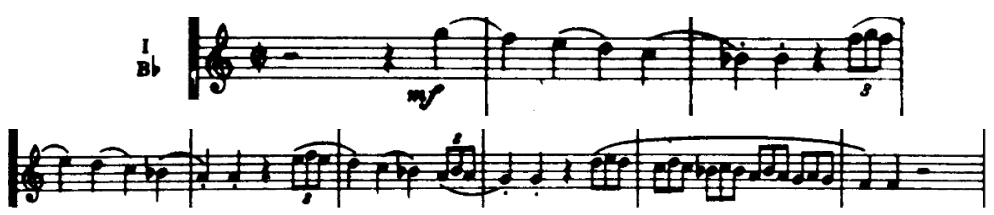

14. kottapélda. Bartók Béla: Concerto zenekarra (Intermezzo interrotto, 75-82. ü.)

Ahogyan a fenti elemzésből kitűnik, a Concerto egyike azoknak a múveknek, amelyben Bartók felhasználta a Törökországban gyüjtött dallamanyagot. Létezik olyan feltételezés is, hogy az anatóliai útja után szerzett, aksak ritmusban írt zenemúvek is a török zenének egyfajta befolyását mutatják. Ennek némiképp ellentmond, hogy a zeneszerző 1936 előtt is használja a ritmust, példa erre a Mikrokozmosz hatodik kötetének Bolgár ritmus elnevezésű darabja. ${ }^{9}$

A Concerto, Bartók utolsó alkotókorszakának egyik mesterműve, különböző forrásokat használ, zseniálisan egyesíti a folklórelemek inspirációit és a nyugati klasszikus zenét. A szer-

9 Az aksak ritmus, más néven bolgár ritmus, hasonló a görög, macedón, török, a kaukázusi ritmusokhoz is. 
ző saját múvéből is idéz benne, a második tételben - Elégia - a könnyek tavát a Kékszakállú herceg várából, illetve dallamot használ Dmitrij Sosztakovics hetedik szimfóniájából és Vincze Zsigmond egyik operettjéből.

Már csak kisebb terjedelme miatt is sokkal kevésbé jelentős a török anyag hatása Bartók alkotásaiban, mint a román, magyar vagy a szlovák folklór inspirációja. Mégis fontos ezt a sajátos szempontot beemelni a Bartók-kutatás további feladatai közé. ${ }^{10}$

\section{BÉLA BARTÓK'S CONCERTO FOR ORCHESTRA. INFLUENCE OF THE TURKISH FOLK MUSIC COLLECTION}

\section{Keywords: Turkish Folk Music Collection, Béla Bartók, inspiration, Concerto}

Béla Bartók's Concerto for Orchestra represents one of the musical masterpieces of the $20^{\text {th }}$ century. In the field of musicology there are countless analyses of this work from different points of view. The Concerto combines elements of Western classical music (for instance the use of the sonata-form) and Eastern European folk music. The influence of the Hungarian, Slovakian, Romanian and Serbian folk music is evident in this work of Bartók, but there is limited information available about the traces of the last collecting tour of the composer and ethnomusicologist in 1936 to Anatolia, Turkey. Besides enumerating different sources of inspiration for this composition, present article aims to identify the influence of the Turkish Folk Music Collection in Béla Bartók’s Concerto.

\section{BÉLA BARTÓK CONCERTO PENTRU ORCHESTRĂ. INSPIRAȚIE TURCEASCĂ ÎNTR-O CAPODOPERĂ}

\section{Cuvinte-cheie: colecţia de muzică populară turcească, Concerto, inspiraţie, Béla Bartók}

Concerto-ul lui Béla Bartók reprezintă una dintre capodoperele muzicale ale secolului XX. S-au publicat nenumărate analize muzicologice din diferite puncte de vedere, deoarece piesa îmbină elemente ale muzicii clasice occidentale (de ex. utilizarea formei de sonată) și a muzicii populare din estul Europei. Impactul muzicii populare maghiare, române, slovace sau sârbe este de necontestat în operele lui Bartók, însă există doar puține date privind inspirațiile provenite din ultima sa culegere, cea din Anatolia în 1936. Pe lângă enumerarea surselor folclorice și clasice ale piesei, lucrarea încearcă să concretizeze influența colecției de muzică populară turcească în Concerto-ul lui Béla Bartók.

10 A dolgozat további forrásai: BArtóк Béla: Turkish Folk Music from Asia Minor. Ed. Benjamin Suchoff. Princeton University Press, 1976; J. Peter Burkholder-Donald Jay Grout-Claude V. Palisca: A History of Western Music. Seventh edition. W.W. Norton\&Norton, New York-London, 2006; David Cooper: Concerto for Orchestra. Cambridge University Press, 1996; Richard L. Crocker: A History of Musical Style. Dover Publications, New York, 2014; Kár Páti János: Bartókanalitika: Válogatott tanulmányok. Rózsavölgyi és társa, Bp., 2003; LAMPERT Vera: Folk Music in Bartók's Compositions: A Source Catalog: Arab, Hungarian, Romanian, Ruthenian, Serbian, and Slovak melodies. Second Edition. Helikon, Bp., 2008; Dobszay László: The Absorption of Folk Song. Studia Musicologica, Akadémiai, Bp., 1982; Lendvai Ernő: Béla Bartók: An Analysis of His Music. Kahn\&Averill, 2001; Lendvai Ernő: Bartók stílusa, Akkord Zenei Kiadó, Bp., 1993; Sipos János: Bartók nyomában Anatóliában; hasonló magyar és török dallamok. Balassi, Bp., 2002; Benjamin Suchoff: Bartók and Serbo-Croatian Folk Music. The Musical Quarterly LVIII(1972). nr. 4.557-571. 